\title{
The Development of Multilateral M ovement Skill Teaching Models Based Games for The 2nd Grade Student of Elementary School
}

\author{
Tri Waluyo ${ }^{1}$, Andiyanto ${ }^{2}$, Ariando Ariston ${ }^{3}$ \\ Departement of Sport Education S2, Faculty of Sports Science, Universitas Negeri Padang \\ Jalan Prof. Dr. Hamka Air Tawar Padang, Sumatera Barat 25171, Indonesia \\ *triwaluyo08@gmail.com¹,*andiyanto.2610@gmail.com², ariandoariston05@gmail.com³
}

\begin{abstract}
Abtract
This research is intended to produce multilateral movement skill teaching models based games for the 2nd grade students of elementary school which are valid, practice, and effective. The aim of this study was to develop a teaching model of multilateral basic movements based on characteristics of students. This produce focused on three basic movement: locomotors, non locomotors, manipulative. To to produce the prototype of the materials, ADDIE model was applied. The development of the teaching model was conducted in five steps: (1) Analyze, (2) Design, (3) Develop, (4) Implement, and (5) Evaluate. The models was revised by using self evaluation and experts review evaluation. In order to see the practicality of the product, the models was tried out by using small group and Field Test Evaluation Method in the 2nd grade of SD Negeri 52 Parupuk Tabing Padang. Meanwhile to see the effectiveness of the learning materials developed, the models was tried out by using field test evaluation method at SD Negeri Percobaan Padang. Based on the results of the research, it is concluded that multilateral movement skill teaching models based games for the 2nd grade students of elementary school are valid, practical, and effective.
\end{abstract}

Keywords:Multilateral Movement, teaching Model, Games, Elementary School

\section{INTRODUCTION}

The child is the owner of the future of the nation, because in his hand the life of the Indonesian people continues. Through good care and education, children are expected to have thoughts, words, deeds (social relations) and good movements so that later children are able to achieve what is their hopes and dreams in the future. One important component in achieving this is body health. A healthy body is the main point for humans to be able to carry out motion activities properly, a healthy body and good motion can be formed and obtained through a suitable activity, namely exercise, as explained by Clark (2008: 54) Sport can help children grow, giving them a sense of achievement while building teamwork, leadership. Problem-solving, decision-making, and comumunications skiils. Sport also enables children to channel their energy, competitiveness and aggression in socially. Sports can help children grow, and give children a sense of accomplishment while building teamwork, leadership, problem solving, decision making, and communication skills. Sports also allow children to channel energy, competitiveness, and social aggression. If the child is able to perform physical activity properly and correctly and continuously, the child will have a healthy body and a variety of good moves.

The need for varied sports activities is very helpful for children in the learning process of motion, as stated by Sukadiyanto (2005: 19) one of the principles of exercise is the principle of variation. With the various forms of learning and training processes children will avoid boredom, reluctance, and anxiety which are psychologically miserable forms that can be an attraction for children in the process of learning various movements.

Basically teachers and trainers have the same hopes and desires to shape students or trained children who are capable of achieving later. To get the expected results, of course, it must go through a process, in which the process must be passed in stages from the most basic 
or simple stages to later going to more complex or difficult stages. Along with the expectations of the teacher, there are many basic processes that cannot be fulfilled to bring children to more complex stages, such as working on various forms of basic movements that are expected to be able to become a child's foundation to move to more complex stages of motion.

The content of Physical Sports and Health Education (PJOK) lessons as a vehicle that provides various forms of basic movements in the learning process to achieve educational goals. PJOK plays an important role in providing opportunities for students to be directly involved in various learning experiences through physical, sports, and health activities. One of the objectives of the PJOK in primary schools is to improve basic movement skills and skills (BNSP, 2006: 195). Thus packaged learning should be in line with curriculum objectives to produce productive, creative, innovative and effective Indonesian people through strengthening attitudes, skills and knowledge.

This makes physical activity a good activity to develop students' behavioral attitudes. Furthermore, which is no less important through physical activity can improve the movement skills of students. This is in accordance with what was suggested by Sujiono (2010: 39) "Playing activities in both the family and school environment are very meaningful for the development of children's abilities"

The preliminary study that the researchers conducted on class II elementary school students who conducted learning activities at the SD Experiment in the city of Padang still found many teacher weaknesses in carrying out the implementation of learning. This is seen from the learning process which still uses traditional methods so that teachers are considered less creative in providing forms of physical activity involving learning various forms of basic motion or multilateral motion.

The findings the researchers got one of them when the teacher taught the child to run, here the teacher only instructed students to run as fast as possible and then gave a signal to the students to run at a predetermined distance. In addition, in basic motion learning materials such as jumping, students are only instructed to jump several times and then run towards the specified direction. When this activity is carried out one or two times the opportunity of the students does look enthusiastic, but for the next opportunity the students look lazy or reluctant to do the same activities.

Researchers assume that this happens because students feel bored and tired so there is no pleasure or excitement for students in doing motion activities. In response to this, the teacher only continues the learning material without any effort to improve the way of teaching and the movements of students in the basic motion learning process. Even though basic motion or multilateral motion is a series of moves that are important for the continued movement of future students.

Based on the above problems, it is necessary to have variations in various forms of basic motion learning processes or multilateral movements in order to foster the enjoyment of students in learning and practicing, so that what is taught and trained by the teacher can be achieved accordingly.

\section{RESEARCH METHOD}

This study uses a research and development approach. The development research model used in this study is the ADDIE development model which is designed to develop a multilateral motion-based learning model for low-grade students in elementary schools. ADDIE is an instructional system design that has often been used to develop various systems, both formal systems, such as in the delivery of educational and nonformal systems, such as in the implementation of training to achieve certain goals. This model consists of 5 main phases or stages, namely; ADDIE consists of five stages, namely: analysis (analysis), design (design), development (development), implementation (implementation), and evaluation (evaluation).

\section{FINDINGS AND DISCUSSION}

\section{Validity of the Game-Based Multilateral Motion Learning Model for Class II Elementary School Students}

Validity is needed to test a study. The word "valid" is often interpreted correctly, correctly, valid, abash, so the word validity can be interpreted with accuracy, truth, validity, or validity (Sudjiono, 1995: 93). Research products are said to be valid if they meet certain criteria. According to Plomp (2007: 127) the characteristics of the product are said to be valid if it reflects the soul of knowledge (state of the art knowledge). This is what is said by content validation. Furthermore, the product components must be consistent with each other (construct validity). Based on the analysis of validation assessment data from the validator, the validity of 
the game-based multilateral motion learning model developed is valid. This can be seen from the results of validation that has been declared valid by the validators, namely with an average validity level of $87.2 \%$ which belongs to the valid category.

\section{Practicalities of Game-Based Multilateral Motion Learning Models for Class II Elementary School Students}

The term practicality in the Large Dictionary of Indonesian Language (1990: 698) means something practical with an easy intention and pleasure in its use. Furthermore, According to Arikunto (2010: 62) explains that practicality or practicality, it means that it is easy to implement, easy to check, and equipped with clear instructions that facilitate teachers and students in the use of learning devices used. To see the implementation of the learning model that has been developed practically or not, an assessment is carried out through observing the implementation of learning. The results of the observation of the implementation of learning that the implementation of the game-based multilateral motion learning model for class II elementary school students is in the very practical category of $91.5 \%$. Based on the results of the model's average implementation, in general the implementation of the game-based multilateral motion learning model for class II elementary school students has been done very well.

\section{Effectiveness of Game-Based Multilateral Motion} Learning Model for Class II Elementary School Students

The term effectiveness in the Big Dictionary of Indonesian Language (1990: 219) means something that is effective which means the effect, effect, influence, it seems. So the effectiveness means the impact, influence, and results generated from an action in this case towards the use of the learning model developed. According to Firman (2000: 56), the effectiveness of the learning program is characterized by the following characteristics: (a) successfully delivering students to achieve predetermined instructional goals, (b) providing an attractive learning experience, actively involving students so as to support achievement instructional goals, (c) have facilities that support the learning process. Aspects of effectiveness can be done if the product has been valid and practical. The effectiveness of the learning model developed can be seen from the learning outcomes of students in the realm of attitudes, knowledge, and skills. To find out how far students can master teaching material, then the learning outcomes test is conducted to test aspects of knowledge. Trianto (2010: 235) suggests "Tests of learning outcomes are items that are used to determine student learning outcomes after participating in learning activities". While on the aspects of attitudes and skills using the assessment rubric. The following is an overview of the average learning outcomes of students using the mulitlateral motion learning model for second grade elementary school students.

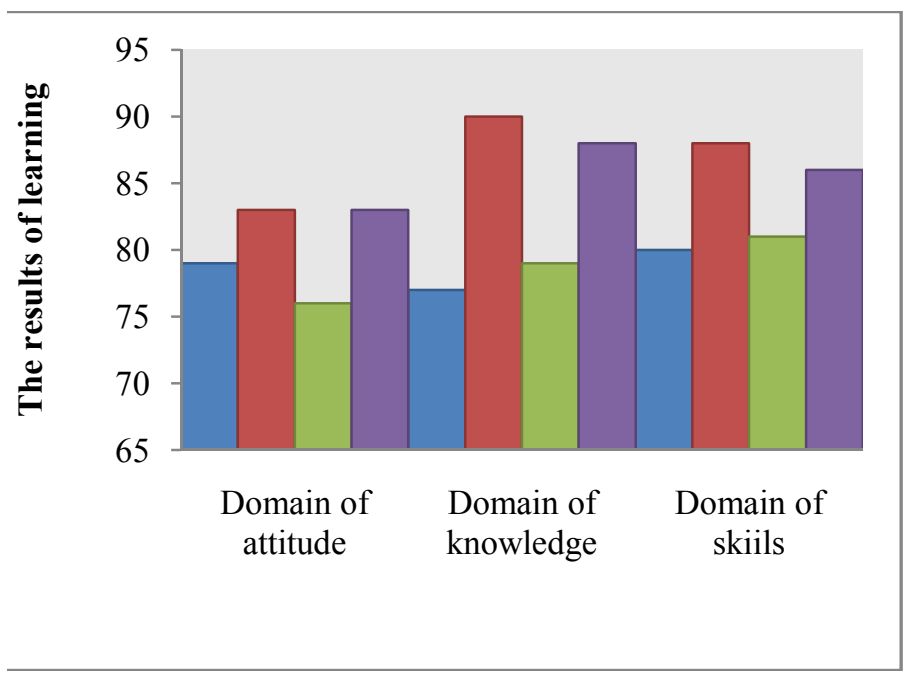

\section{a. Domain of attitude}

The results of effectiveness on the realm learning outcomes attitude at the small-scale trial stage before using the Game-Based Mulitlateral Motion Learning Model for Class II Elementary School Students the average student achievement score is 79 with good qualifications (predicate B) and at the learning stage using the model there is an increase in attitude learning outcomes with an average score of 83 with good qualifications (predicate B). The results of $t-$ test calculations show that the value of tcount $=3.021$ while the $\mathrm{t}$-value is 1.729 with a sign level $(\square)$ of 0.000 . The value of tcount is greater than $t$ table $(3,021>1,729)$. It was concluded that Ho was rejected and H1 was accepted. Sign level $(\square)$ count is smaller or equal to $\square=0.05$. Meanwhile, in the large scale trial the attitude of learning outcomes also increased from the average achievement of students who were 
previously 78 with good qualifications (predicate B) to an average of 88 with good qualifications (predicate B). From the above learning outcomes that have been achieved and the correlation test it can be concluded that multilateral motion learning models are based on effective games to improve the learning outcomes of students' attitudes in learning physical sports and health education in grade II elementary school.

\section{b. Knowledge area}

The results of the effectiveness of knowledge learning outcomes at the smallscale trial stage before using the GameBased Mulitlateral Motion Learning Model for Class II SD Students the average student achievement score is 77 with good qualifications (predicate B) and at the learning stage using the model there is an increase in skills learning outcomes with an average score of 93 with excellent qualifications (predicate A). On the results of the calculation of the $t$ test it can be seen that the value of $t$ count $=7.935$ while the value of $t$ table is 1.729 with the level of sign ( $\square$ ) of 0,000 . The tcount is greater than $t$ table $(7,935>1,729)$. It was concluded that Ho was rejected and H1 was accepted. Sign level $(\square)$ count is smaller or equal to $\square=$ 0.05 . Furthermore, in the large-scale trial the attitude of learning outcomes also increased from the average achievement of students who were previously 76 with good qualifications (predicate B) to an average score of 83 with good qualifications (predicate B). From the learning outcomes that have been achieved and the correlation test it is concluded that the multilateral motion learning model based on the game is effective in improving the learning outcomes of the students' knowledge in learning physical sports education and health in grade II elementary school. The final results obtained are in accordance with the stated objectives $>80 \%$ of students complete their study, so that classically reviewed PJOK learning outcomes in the realm of knowledge by using a game-based multilateral motion learning model is said to be complete.

\section{c. Skills}

The results of effectiveness on the realm learning outcomes of skills at the small-scale trial stage before using the Game-Based Mulitlateral Motion Learning Model for Class II SD Students the average student achievement scores are 80 with good qualifications (predicate B) and at the learning stage using the model there is an increase in skills learning outcomes with an average score of 88 with good qualifications (predicate B). On the results of t-test calculations, it can be seen that the value of tcount $=6.335$ while the t-value is 1.729 with the sign level $(\square)$ of 0.000 . The tcount is greater than $t$ table $(6,335>1,729)$. It was concluded that Ho was rejected and $\mathrm{H} 1$ was accepted. Sign level ( $\square$ ) count is smaller or equal to $\square=0.05$. Furthermore, in the largescale trial the attitude of learning outcomes also increased from the average achievement scores of students who were previously 81 with good qualifications (predicate B) to an average of 86 with good qualifications (predicate B). The results of the calculation of the $\mathrm{t}$ test show that the value of tcount $=$ 3.442 while the value of ttable is 1.706 with a sign level ( $\square$ ) of 0.000 . The tcount is greater than $t$ table $(3.442>1.706)$. It was concluded that Ho was rejected and H1 was accepted. Sign level ( $\square$ ) count is smaller or equal to $\square=0.05$. Based on the learning outcomes that have been achieved, it can be seen that learning using a multilateral motion-based learning model for grade II elementary school students can help students improve aspects of their skills. This is illustrated by the existence of a significant difference between the skills learning outcomes before and after using a multilateral motion-based learning model in elementary school class II. From the learning outcomes that have been achieved and the correlation test it can be concluded that multilateral motion-based learning models improve the learning outcomes of the field. skills of students $d$ 


\section{CONCLUSIONS, AND SUGGESTIONS}

Based on the development and trial of the learning model that has been carried out, a multilateral motion-based learning model has been produced for elementary school students in accordance with the curriculum, concepts, and characteristics of valid students with an average value of expert validator score of $87.2 \%$. . This illustrates that the learning model developed has been valid and can be used in PJOK learning in class II elementary school. Practicality of the model shows that the game-based multilateral motion learning model for class II elementary school students is classified as very practical. It is seen from the implementation of the model by the teacher on the implementation of the model in learning which results in an evaluation of learning implementation of $91.5 \%$. The results of the analysis on the effectiveness test with the experiment (Sig2 tiled $<0.5)$ on the game-based multilateral motion learning model for class II elementary school students showed that the model was effective in improving student learning outcomes in the areas of attitudes, knowledge, and skills. This is seen from the difference between the acquisition of student learning outcomes before using the model after using the model (Before-after).

For elementary PJOK teachers, based on the results of validity, practicality and effectiveness that have been implemented, the Game-Based Multilateral Motion Learning Model can be used as an alternative in teaching motion learning material, especially for grade II elementary school. Other researchers, can develop a Game-Based Multilateral Motion Learning Model on other material and further on the broader scope of the school with different situations and conditions to get more perfect results. The development model that has been developed can be used as a reference in developing other models, especially those related to PJOK learning in elementary schools.

\section{REFERENCES}

[1] Allesi, S.M., \& Trollip, S.R. 2001. Multimedia for Learning Method and Development. Boston: Omegatype Typography, Inc.

[2] BNSP. 2006. Standar Kompetensi dan Kompetensi Dasar Pendidikan Jasmani, Olahraga, dan Kesehatan Sekolah Dasar dan Madrasah Ibtidaiyah. Jakarta: Kemendikbud

[3] B.E.F Montolalu, dkk. 2014. Bermain dan Permainan Anak. Tangerang Selatan: Universitas Terbuka.

[4] Bompa, T.O. 2010. Total Training for Young Champoins. Windsor: New York University.
[5] Branch, R. M. 2009. Intructional Design The Addie Aproach. New York: Springer SciencepBusiness Media, LLC. Diakses dari http:// www.zultigaltp.com. Diakses pada tanggal 30 Februari 2018.

[6] Caillois, R. 2001. Man, Play, and Games. (Terjemahan Mayer Barash). Paris: Librarie Gallimard.

[7] Clark, W. 2008. Kid's Sport. Competent of Statistic Canada Catalogue no. 11-008-X Canadian Social Trends. Diakases pada tanggal 21 Juni 2017, http://www.statcan.gc.ca/pub/PP-008$\mathrm{x} / 2008001 /$ article/10573-eng.htm

[8] Departement of Sport and Recreation Government of Western Australia. 2013. Fact and Stats Benefits of Physical Activity. Diakses pada tanggan 19 Agustus 2017 , www.Vicsport.asn.auAssetFilesWADSR \%20\%20Be nefits $\% 20 \%$ Physical\%Activity.Pdf

[9] Gunarsa, D. S. 2008. Psikologi Olahraga Prestasi. Jakarta: PT BPK Gunung Mulia. [ 50 ]

[10] Gusril. 2008. Model Pengembangan Motorik Siswa Sekolah Dasar. (Padang, FIK UNP-Dikti)

[11] Irianto, D.P. 2002. Dasar Kepelatihan. Diktat Mata Kuliah Kepelatihan, Program Studi Pendidikan Kepelatihan Olahraga, Fakultas Ilmu Keolahragaan, Unıversitas Negeri Yogyakarta.

[12] Latif, M., et,al. 2013. Orientasi Baru Pendidikan Anak Usia Dini Teori dan Aplikasi. Jakarta: Kencana Prenada Media Grup.

[13] Lillard, A.S 2013. Playful Learning and Montessori Education. American Journal of play, volume 5, number 2. www. ProQuest.com diakses pada tanggal 21 Desember 2017.

[14] Lumintuarso, R. 2013. Pembinaan Multilateral bagi Atlet Pemula. Yogyakarta: UNY Press.

[15] Metzler, M. 2005. Instructional Models For Physical Education. Scottsdale, Arizona : Holocomb Hathaway Publisher Inc.

[16] Nopembri, Soni dan Sumaryoto. 2014. Buku Guru Pendidikan Jasmani, Olahraga, dan Kesehatan SMA/MA SMK/MAK Kelas XI. Jakarta: Pusat Kurikulum dan Perbukuan, Balitbang, Kemendikbud. ( Di Unduh dari http://bse.kemendikbud.go.id ).

[17] Sugiyono. 2010. Metode Penelitian Kuantitati, Kualitatif, dan R\&D. Bandung: CV. Alfabeta.

[18] Sujiono, Y.N \& Sujiono, B. 2010. Bermain Kreatif Berbasis Kecerdasan Jamak. Jakarta: PT. Indeks

[19] Sukadiyanto. 2005. Mettodologi Melatih Fisik. Yogyakarta: Universitas Negeri Yogyakarta.

[20] Sukintaka. 1992. Teori Bermain unutuk D2 PGSD Penjaskes. Jakarta: Departemen Pendidikan dan Kebudayaan.

[21] Suyanto \& Jihad, A. 2013. Menjadi Guru Profesional Strategi Meningkatkan Kualifikasi dan Kualitas Guru di Era Global. Jakarta: Esensi.

[22] Tedjasaputra. 2001. Bermain, Mainan, dan Permainan. Jakarta: PT. Gramedia Widiasararana Indonesia.

[23] UNICEF. 2004. Sport Recreation And Play. New York: United Nation Children's Fund Division of Communcation 3 United Nation Plaza.

[24] Upton, P. 2012. Psikologi Perkembangan. (Terjemahan Noermalasari Fajar Widuri). New 
York: Pearson Education. ( Buku Asli diterbitkan 2012)
[25] Wiradiharja, S. 2010. Pengembangan model latihan gerak multilateral pada anak usia dini. Isu-isu kritis dalam pendidikan. 